\title{
Methane emissions in selected hard-coal mines of the Upper Silesian Coal Basin in 1997-2016
}

\author{
Marcin Dreger \\ University of Silesia in Katowice, Faculty of Earth Sciences, Department of Applied Geology; \\ ul. Będzińska 60, 41-200 Sosnowiec, Poland; e-mail: marcin.dreger@interia.pl; ORCID ID: 0000-0002-7250-2523
}

(C) 2019 Author. This is an open access publication, which can be used, distributed and reproduced in any medium according to the Creative Commons CC-BY 4.0 License requiring that the original work has been properly cited.

Received: 26 November 2018; accepted: 12 June 2019; first published online: 30 June 2019

\begin{abstract}
Hard coal is extracted in the Upper Silesian Coal Basin (USCB) from deeper and deeper coal seams every year. In 2000, the average depth of coal extraction was $600 \mathrm{~m}$, in $2010-700 \mathrm{~m}$, but in the last two years (2016-2017) this has been extended to a depth of $770 \mathrm{~m}$. The USCB is not homogeneous in layout in terms of methane hazard, but rather very diverse. Therefore, the USCB has been divided into seven gassy regions to show differences in methane danger distribution.

Northern and central USCB regions (I, II and III) are the mostly naturally degassed, so the most dangerous gassy conditions are in the IV and V regions, where methane content in coal seams varies from $6 \mathrm{~m}^{3} / \mathrm{Mg}$ coaldaf to above $18 \mathrm{~m}^{3} / \mathrm{Mg}$ coal ${ }^{\text {daf }}$. The two westernmost USCB gassy regions (VI and VII) are poorer in methane than the IV and $\mathrm{V}$ areas.

Six representative coal mines were chosen: Mysłowice-Wesoła, Budryk, Brzeszcze, Pniówek, Marcel and Rydultowy-Anna based on their high hard coal production and total methane emissions. The reason for the highest methane emission in those regions might be fault tectonics facilitating methane migration and also the thick and continuous Miocene cover constituting a hermetic screen for gases in the southern part of the USCB.
\end{abstract}

Keywords: The Upper Silesian Coal Basin (USCB), total methane emission, hard coal production, methane hazard, specific methane emission

\section{INTRODUCTION}

The Upper Silesian Coal Basin (USCB) is located in Poland $\left(5,600 \mathrm{~km}^{2}\right)$ and in the Czech Republic $\left(1,900 \mathrm{~km}^{2}\right)$. The most important fuel for the Polish economy is hard coal, $80 \%$ of which occurs in the USCB (Mizerski 2014: 133-134). One fifth of the coal basin is constituted by coal deposits which are operated (Tab. 1). From year to year, Polish mines need to extract hard coal from deeper and deeper coal seams to maintain profitability and keep thousands of workplaces safe. Reaching deeper coal seams results in increasing the danger posed by methane (Kotarba \& Ney 1995, Szlązak 2015). There are two simplified geological settings of vertical distribution of coal-bed methane in the USCB (Kotas 1994). The northern and middle-eastern regions of the USCB (Fig. 1A) are characterised by the occurrence of naturally degassed coal seams to the depth of 500-600 m. In these regions, Carboniferous deposits are covered by thin and permeable Triassic, Jurassic and Quaternary formations with local patches of impermeable Miocene deposits. As the depth increases, methane content increases rapidly until it reaches the primary methane maximum between 1,200 and $1,600 \mathrm{~m}$ (Fig. 1A).

The southern and south-western regions of the USCB are characterized by the occurrence of two maxima of methane content (Fig. 1B). The first 
includes the secondary accumulation of methane adsorbed in coal seams underlying the impermeable Miocene cover. The deeper lying primary methane maximum reaches a depth of $1,200 \mathrm{~m}$ and more. These two maxima are separated by an interval of minimum methane content (Kotas 1994, Kędzior 2012).
The purpose of this article is to show how methane emissions have changed against the background of hard coal production in 1997-2016 in six representatives coal mines and in the entire USCB. It will show dependences between methane emission, coal production and their location in the basin.

\section{Table 1}

Types of coal deposits with area coverage (modified after Mizerski 2014: 133-134)

\begin{tabular}{|l|c|c|}
\hline \multicolumn{1}{|c|}{ Coal deposits } & Area $\left[\mathbf{k m}^{2}\right]$ & USCB area [\%] \\
\hline Operated & 1,100 & 20 \\
\hline Reserved & 1,100 & 20 \\
\hline Exploited out or abandoned & 842 & 15 \\
\hline Perspective & 1,291 & 23 \\
\hline Prognostic and with $>1,000$ m overburden & 1,267 & 22 \\
\hline
\end{tabular}
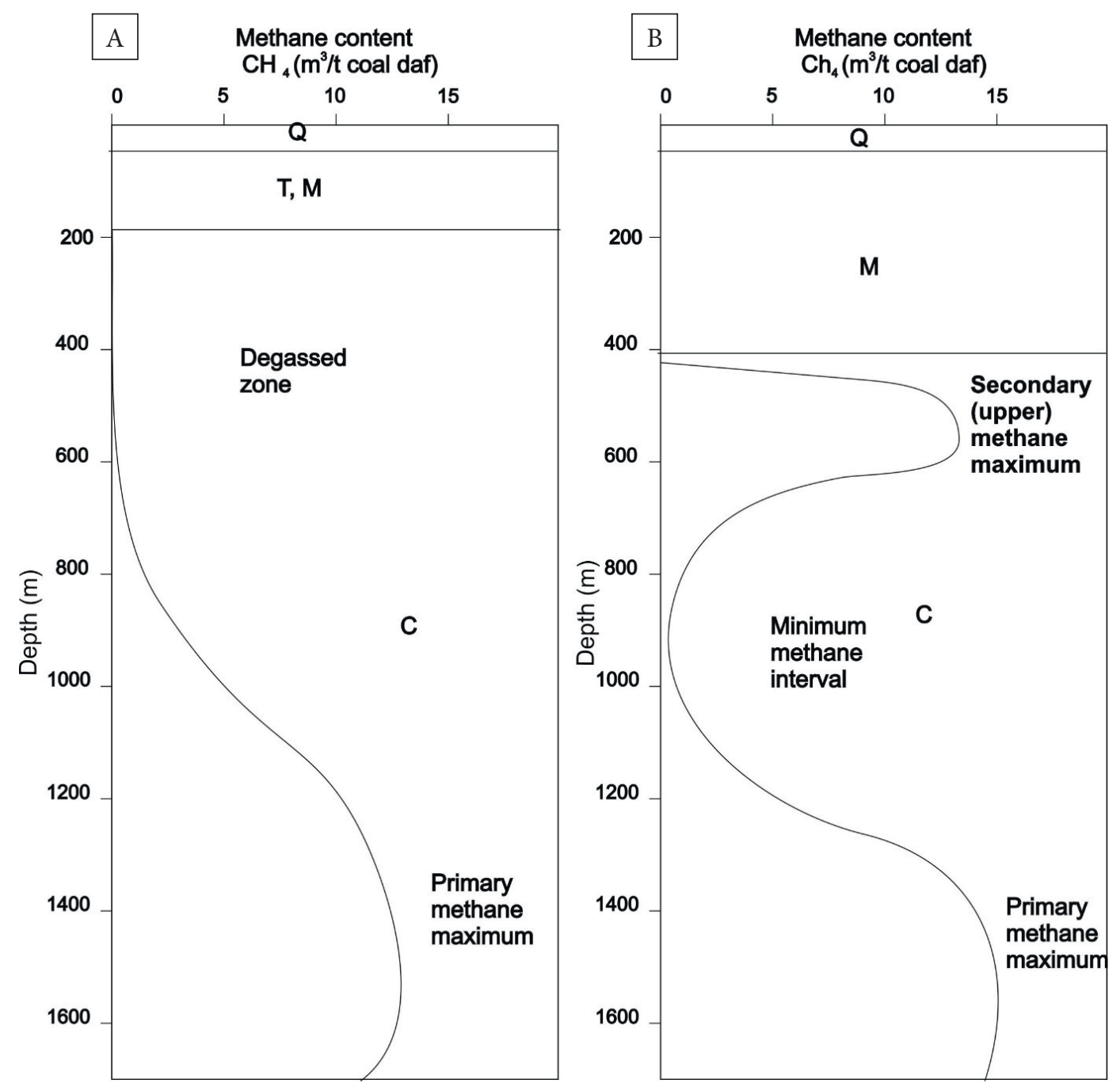

Fig. 1. Methane distribution in the northern (model A) and southern (model B) region of the USCB (modified after Kotas 1994, Kędzior 2012, 2015a, 2015b): Q - Quaternary, T - Triassic, M - Miocene, C - Carboniferous deposits 


\section{METHOD}

To examine how methane emissions changed in the USCB between 1997-2016, the division into seven gassy regions proposed by Kotarba \& Ney (1995) was applied. In the selected areas, six representative coal mines were chosen: Mysłowice-Wesoła, Budryk, Brzeszcze, Pniówek, Marcel and
Rydułtowy-Anna (Fig. 2). The southern V gassy region has no representative, because the Morcinek mine was the only mine which could have been taken into consideration in the research, but it was closed in 1998, after just 11 years of coal production. Six coal mines were chosen based on their high hard coal production and methane emissions in each gassy region.

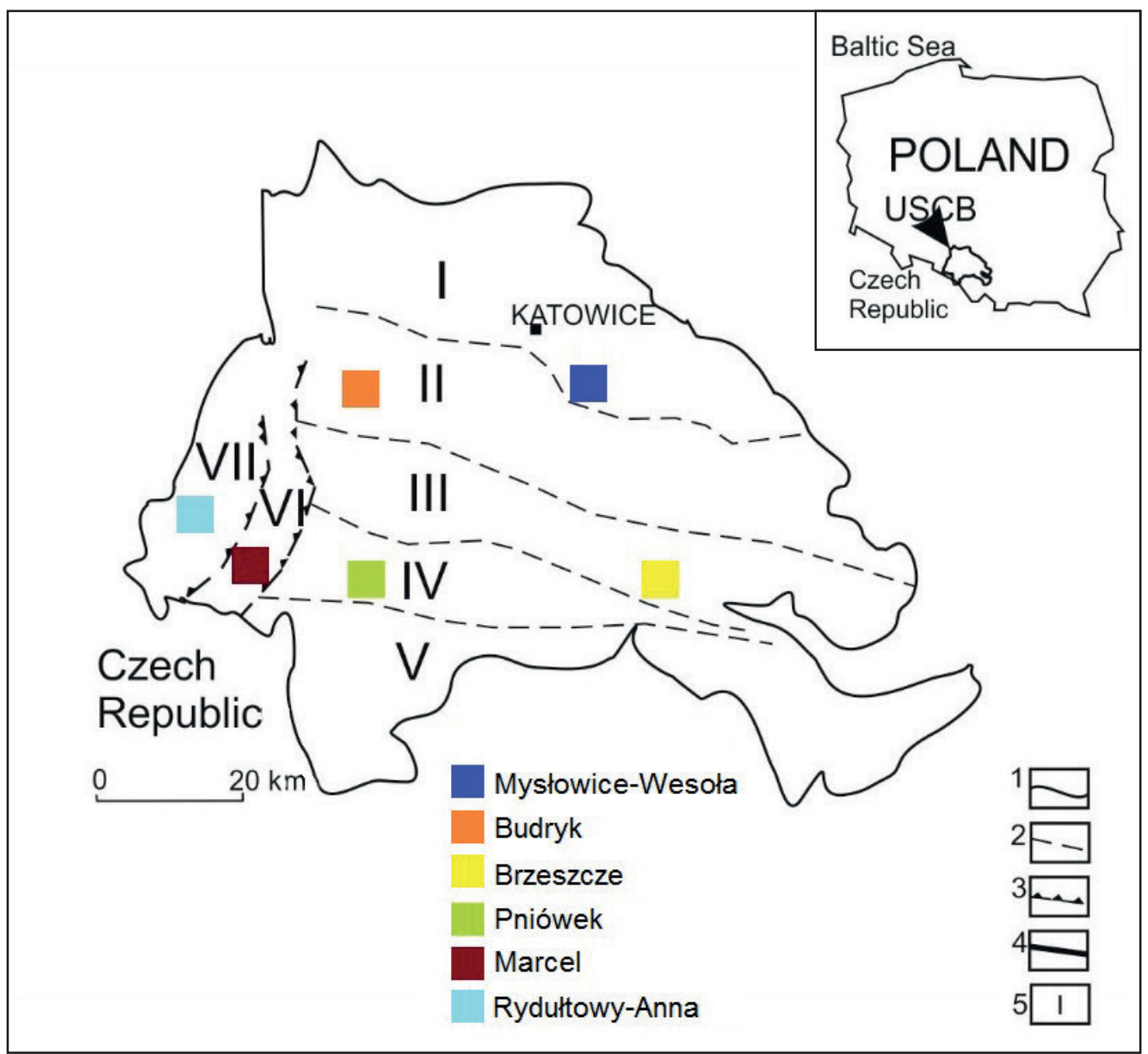

Fig. 2. Mines and gassy regions location in the USCB (modified after Kotarba \& Ney 1995): 1 - the USCB boundary, 2 - main faults, 3 -overthrusts, 4 - the areas boundaries, 5 - area number

Each of the selected mines stands out from the rest in the region in terms of their very high and stable hard coal production and $\mathrm{CH}_{4}$ emission - making them representative mines. Most of the data including hard coal production and methane emissions were obtained from the $A n-$ nual report about basic natural and technical hazards in hard coal mining (Raport... 1998-2017). In the paper, the total methane emissions are presented as a sum of the average yearly ventilation methane emission and $\mathrm{CH}_{4}$ captured by underground drainage system (mine degasification). After data analysis including hard coal production and methane emissions in the whole USCB and in the selected coal mines, charts were made to show how important values changed over the course of the research period (1997-2016). 


\section{GEOLOGICAL OUTLINE,} METHANE OCCURRENCE AND DISTRIBUTION IN THE UPPER SILESIAN COAL BASIN

Methane occurs in coal deposits in the form of free and sorbed methane. Free methane fills voids, pores and breaks in coal seams and surrounding barren rocks. In the USCB coal deposits $\mathrm{CH}_{4}$ occurs mainly as adsorbed methane (tied gas), which is connected with coal physically or chemically. During coal extraction, the adsorbed gas is released into the coal mine workings and thus methane danger increases (Honysz 2015).

The USCB has been divided into seven gassy areas (Fig. 2) (Kotarba \& Ney 1995) differing in gassy and geological conditions. The main faults (i.e. Kłodnica, Bełk, Jawiszowice and Bzie-Czechowice) and two main overthrusts (Orłowa-Boguszowice and Michałkowice) constitute the boundaries between these areas.

The short characteristics of the seven main gassy regions presented below are based on previous research (Kotarba \& Ney 1995, Grzybek \& Kędzior 2005).

I gassy region is the most northerly situated area bordering the USCB range in the north and Kłodnica Fault in the south (Fig. 2). The most characteristic feature for this area is the lack of Miocene cover. Carboniferous overburden is built from permeable Triassic, Jurassic and Quaternary deposits of 0-300 m thickness. These lithological conditions have helped coal-bearing rock formations in degassing in the past.

II gassy region is located between two dislocations: Kłodnica Fault (North) and Bełk Fault (South). Carboniferous formations are mostly uncovered by younger deposits. Only in the western part of this gassy area do Miocene deposits occur (of a thickness up to $300 \mathrm{~m}$ ). The remaining overburden consists of permeable Triassic, Jurassic and Quaternary deposits.

III gassy region is situated between Bełk Fault in the north and Jawiszowice Fault located in the south. The overburden is built with hermetic Miocene deposits with thicknesses varying from 100 to $500 \mathrm{~m}$. In the Carboniferous profile sandstones of the Cracow Sandstone Series (CSS) (where porosity reaches $15-20 \%$ ) this helped methane to migrate and finally, significantly degassed the CSS coal seams in the past.
IV gassy region is between Jawiszowice Fault in the north and Bzie-Czechowice Fault in the south. Coal areas situated close to Bzie-Czechowice Fault are characterized by methane migrating from deeper parts of the rock mass to upper lying coal seams. Thick and continuous Miocene cover (from 200 to $1,000 \mathrm{~m}, 400 \mathrm{~m}$ in average) prevented methane from being naturally released to the atmosphere in the past.

$\mathrm{V}$ gassy region is located far to the south and borders Bzie-Czechowice Fault from the north. Similarly, to the IV gassy region, the Miocene cover with a high thickness (from 700 to $1,400 \mathrm{~m}$ ) favours $\mathrm{CH}_{4}$ to accumulate just below Miocene sandstones and claystones.

Two westernmost VI and VII gassy regions are situated within Orłowa-Boguszowice, and Michałkowice overthrusts (folded USCB zone). These tectonic elements, with a permeable deposit character, mean that peripheral areas have been degassed. Even in the presence of Miocene cover, most of the western coal outcrops are naturally out of gas which may indicate that Miocene cover deposits are not hermetic.

Generalizing, northern and central areas I-III are mostly naturally degassed, but methane content can oscillate around $10 \mathrm{~m}^{3} / \mathrm{Mg}$ coal ${ }^{\mathrm{daf}}$ in region II at $800-1,200 \mathrm{~m}$ depth (indigenous high methane zone). The most important factor which prevents methane from being released to the atmosphere in the southern USCB part is the impermeable Miocene cover, with thicknesses varying from 200 to $1,400 \mathrm{~m}$, thus methane content in the USCB southern areas is very high (e.g. Tarnowski 1962, 1989). The first high methane zone occurs between 250 and $800 \mathrm{~m}$, with methane content exceeding $10 \mathrm{~m}^{3} / \mathrm{Mg} \mathrm{coal}^{\text {daf }}$. The secondary $\mathrm{CH}_{4}$ that saturated coal seams occur in these zones. The second-high methane zone is present from 600 to $1,400 \mathrm{~m}$, with methane content up to $22 \mathrm{~m}^{3} / \mathrm{Mg}$ coaldaf. In this way, the whole profile is highly methane rich. Two westernmost USCB gassy regions (VI and VII) are poorer in methane than IV and V areas with maximum methane content in the first (shallow) high methane zone around $5 \mathrm{~m}^{3} / \mathrm{Mg}$ coald ${ }^{\text {daf }}$. Methane content up to $18 \mathrm{~m}^{3} / \mathrm{Mg}$ coal ${ }^{\text {daf }}$ occurs in second (deeper), indigenous high methane zone between 400-1,200 m depth (Grzybek \& Kędzior 2005, Kędzior 2009). 


\section{RESULTS AND DISCUSSION}

\section{Hard coal production}

The extraction of hard coal depends on many factors such as economic, political and geological conditions. When there are too many adversities, coal production is not always profitable. In the Upper Silesian Coal Basin, the trend of hard coal production is decreasing. In 1997, all Polish mines extracted over 133 million Mg of hard coal (Fig. 3) but by the end of the studied period (2016), coal production was around 61 million Mg (Raport... 1998-2017). It is clear to see that over the course of twenty years, coal production dropped by $55 \%$. The biggest drop was noticed in first four years (1997-2000) when coal output decreased from 133.64 to 97.98 million $\mathrm{Mg}$ ( $23.7 \%$ drop).

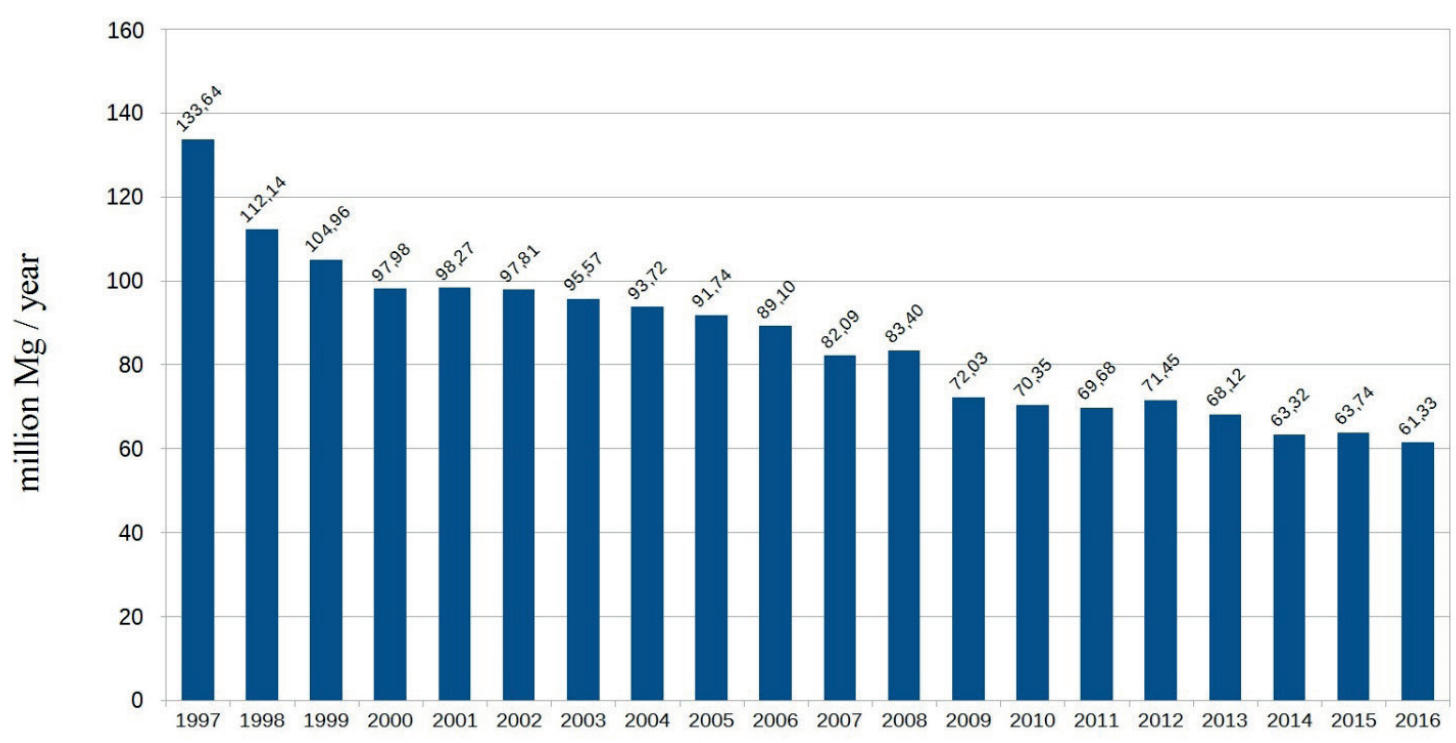

Fig. 3. Hard coal production in the Upper Silesian Coal Basin (Raport... 1998-2017)

\section{Hard coal production in representative coal mines in the first half of the studied period (1997-2007)}

Hard coal production has been split into two periods: from 1997 to 2007 and 2007-2015, because the values of produced coal are very different in these two time periods (Fig. 4).

The Mysłowice-Wesoła mine, the representative coal mine from region I, in the first year of the study (1997) produced the hardest coal through all research period - almost 6 million Mg (Raport... 1998-2017). In the next ten years, the mine exploited around 5 million $\mathrm{Mg}$ of coal annually. At the same time, the Rydułtowy-Anna mine from region VII produced over 4 million $\mathrm{Mg}$ of hard coal per year (1997-2002) and over 3 million Mg annually over the next four years (2003-2006). The rest of the mines were extracted coal at similar levels with periodic drops and rises. Marcel (region VI) produced the most coal in 1997 - over 4 million Mg and up to 2003 ( 2 million $\mathrm{Mg}$ ) the mine noticed constant fall. To the end of the 2007, Marcel output was less than 2.5 million of coal annually. Hard coal output in Pniówek (region IV) was on the most stable level unlike the coal output background of other mines, and fluctuates from 3.4 to 3.7 million $\mathrm{Mg}$ per year. Brzeszcze (region III) extracted 2.85 million $\mathrm{Mg}$ of hard coal in 1997 (the highest production). To the end of 2007, Brzeszcze mine produced more than 2.2 million $\mathrm{Mg}$ of coal annually with single drop in 2003 (1.8 million Mg). Hard coal production under 2 million Mg per year has started in 2006 and continues to these days. Budryk (region II) is the only mine which had been increasing coal production from year to year in the first half of studied period apart from the first three years of the study (19971999). In 1997 Budryk produced 2.4 million $\mathrm{Mg}$ of hard coal. In 1998 and 1999 coal output was just lower by an average of 0.15 million Mg. From 2000 (2.7 million Mg) to 2007 (3.4 million Mg) coal production had been constantly growing. 


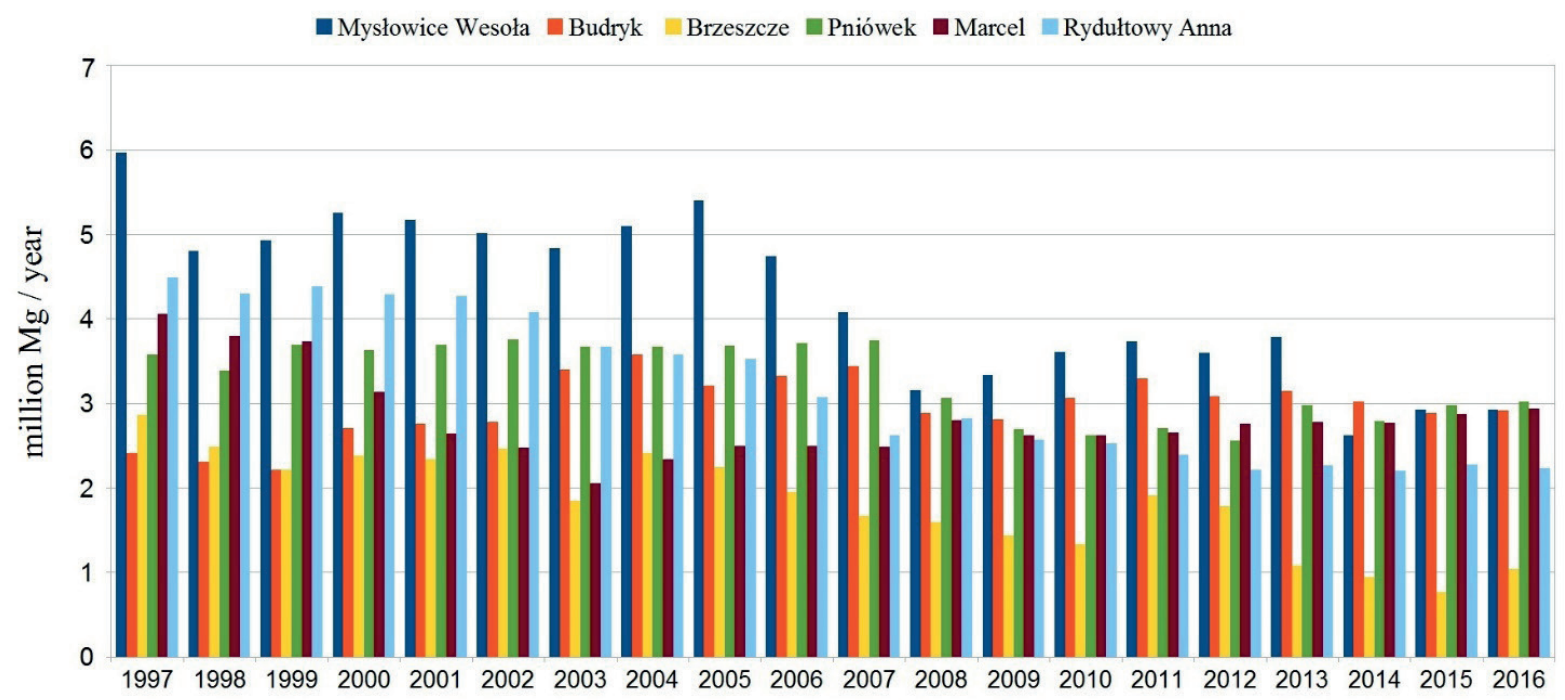

Fig. 4. Hard coal production in representative coal mines (Raport... 1998-2017)

\section{Hard coal production in representative coal mines in the second half of the studied period (2007-2016)}

Mysłowice-Wesoła was a hard coal production leader between 2008 and 2013, extracting from 3.1 to 4.1 million $\mathrm{Mg}$ of coal. In the last three years (2013-2016) hard coal output was less than 3 million $\mathrm{Mg}$ per every year. Exploitation of hard coal in the Budryk mine after 2007 shows no increasing trend as was the case in the first part of the studies. From 2008 to 2016, hard coal extraction was on a similar level, oscillating around 3 million $\mathrm{Mg}$ with short-term fluctuations. In Brzeszcze, a gentle fall has been noticed in 2008-2010 from 1.58 to 1.33 million $\mathrm{Mg}$. In the next two years hard coal output increased to 1.9 and 1.8 million $\mathrm{Mg}$ in 2011 and 2012. Unfortunately, that trend did not last long and the period 2013-2016 was the worst in Brzeszcze's exploitation history. In 2013 coal output was 1.1 million $\mathrm{Mg}$ but in the two last years (2015-2016) coal production amounted 0.9 million $\mathrm{Mg}$ and 0.76 million $\mathrm{Mg}$ respectively. The Pniówek mine opened in the second part of study, with 3.06 million $\mathrm{Mg}$ of hard coal extracted. Unfortunately, subsequent years were characterized by coal production of less than 3 million $\mathrm{Mg}$. It was 2.76 million $\mathrm{Mg}$ of coal average in 20092015 period. In 2016, coal production slightly increased, exceeding 3 million Mg. The history of
Marcel's coal production in the second half of the research period was quite different compared to the first half, being characterized by sudden falls and gentle rises. From 2008 to 2016 hard coal extraction oscillated around 2.75 million $\mathrm{Mg}$, approaching 3 million in 2016. Rydułtowy-Anna's hard coal output is very similar to Marcel's. The volume of extraction is lower than in the Marcel mine, but the trend is very similar - hard coal production remaining on a similar level with gentle fluctuations. In the second part of the study, the highest coal extraction was in $2008-2.8$ million $\mathrm{Mg}$, but the average production was around 2.4 million Mg during the 2008-2016 period.

The second half of studied period (2007-2016) was characterized by lower hard coal production but on more stable level. Most of the mines kept coal production between 2 and 3 million $\mathrm{Mg}$ per year. In the first half of the study, three mines exceeded 4 million Mg of coal extracted (Mysłowice-Wesoła, Rydułtowy-Anna and Marcel) but in the second part of studies, the best result was the extraction of exceeded over 3 million $\mathrm{Mg}$ by three mines (Mysłowice-Wesoła, Budryk and Pniówek).

\section{Total methane emissions}

Ventilation methane emissions and degasification - the sum of these two figures gives a figure of the total methane emissions. The amount of emitted methane in one year (in million cubic meters) 
is composed of average monthly added values of $\mathrm{CH}_{4}$ releasing to mine workings, mixed with mine air and discharge by vent shafts to the atmosphere (Ventilation Air Methane "VAM" emission). The second element is methane captured from drainage systems, when methane is the main component in gas mixture. It helps to work in much safer conditions with reduced content of $\mathrm{CH}_{4}$ (Frączek 2005).

The Brzeszcze and Pniówek mines emitted the most $\mathrm{CH}_{4}$ over the entire studied period. These two mines are situated close to the Jawiszowice Fault (Brzeszcze mine) and Bzie-Czechowice Fault (Pniówek mine) (Fig. 2). The thick Miocene cover and permeable fault action aided methane accumulation in the Pniówek coal seams. The Brzeszcze coal field is located like Pniówek in gassy region IV, nearby permeable large fault zones which helps methane to migrate from deeper lying seams to shallower parts of coal deposits and thus enlarges the methane hazard.

From the beginning of the studies to the end (1997-2016), total $\mathrm{CH}_{4}$ emissions in Pniówek mine were always higher than the methane emissions in Brzeszcze mine (Fig. 5). Only in two periods did these two mines emit similar amounts of methane - in 2001 and 2002 around 113 million $\mathrm{m}^{3}$ of methane annually (Raport... 1998-2017). The second period was in $2009\left(122\right.$ million $\left.\mathrm{m}^{3}\right)$ and 2010 (117 million $\mathrm{m}^{3}$ of $\mathrm{CH}_{4}$ ). The most methane was emitted in Pniówek in 2004-2007 when an average of 135 million $\mathrm{m}^{3}$ of $\mathrm{CH}_{4}$ was released into coal mine workings. In 1997, over 124 million $\mathrm{m}^{3}$ of $\mathrm{CH}_{4}$ was emitted in Brzeszcze - it was the highest methane release in Brzeszcze's research period. Only 3 million $\mathrm{m}^{3}$ of gas was emitted in 2009, when the mine from region III approached Pniówek's methane emissions.

The Budryk mine, situated in gassy region II, emitted less than 60 million $\mathrm{m}^{3}$ of $\mathrm{CH}_{4}$ annually throughout the entire study period. However, in the last four years (2013-2016) total methane emissions suddenly increased. This is closely connected with the indigenous high methane zone which occurs in II gassy region between 800 and $1,200 \mathrm{~m}$ below ground level. A second important factor is that Budryk is the deepest coal mine in Poland, with a newly developed level at 1,290 m below the surface, where coking coal is operated. (Madeja 2017)

In 2013, over 57 million $\mathrm{m}^{3}$ of $\mathrm{CH}_{4}$ were released into Budryk coal mine workings. One year later, the total methane emission increased by 13 million $\mathrm{m}^{3}$ and, two years later, by 18 million $\mathrm{m}^{3}$ of $\mathrm{CH}_{4}$ In the last year of studies (2016) a record value was noticed - over 146 million $\mathrm{m}^{3}$ of methane was emitted by the Budryk mine. It is a $1,063 \%$ increase in relation to the weakest period - 1997 - when only 13,77 million $\mathrm{m}^{3}$ of methane was emitted.

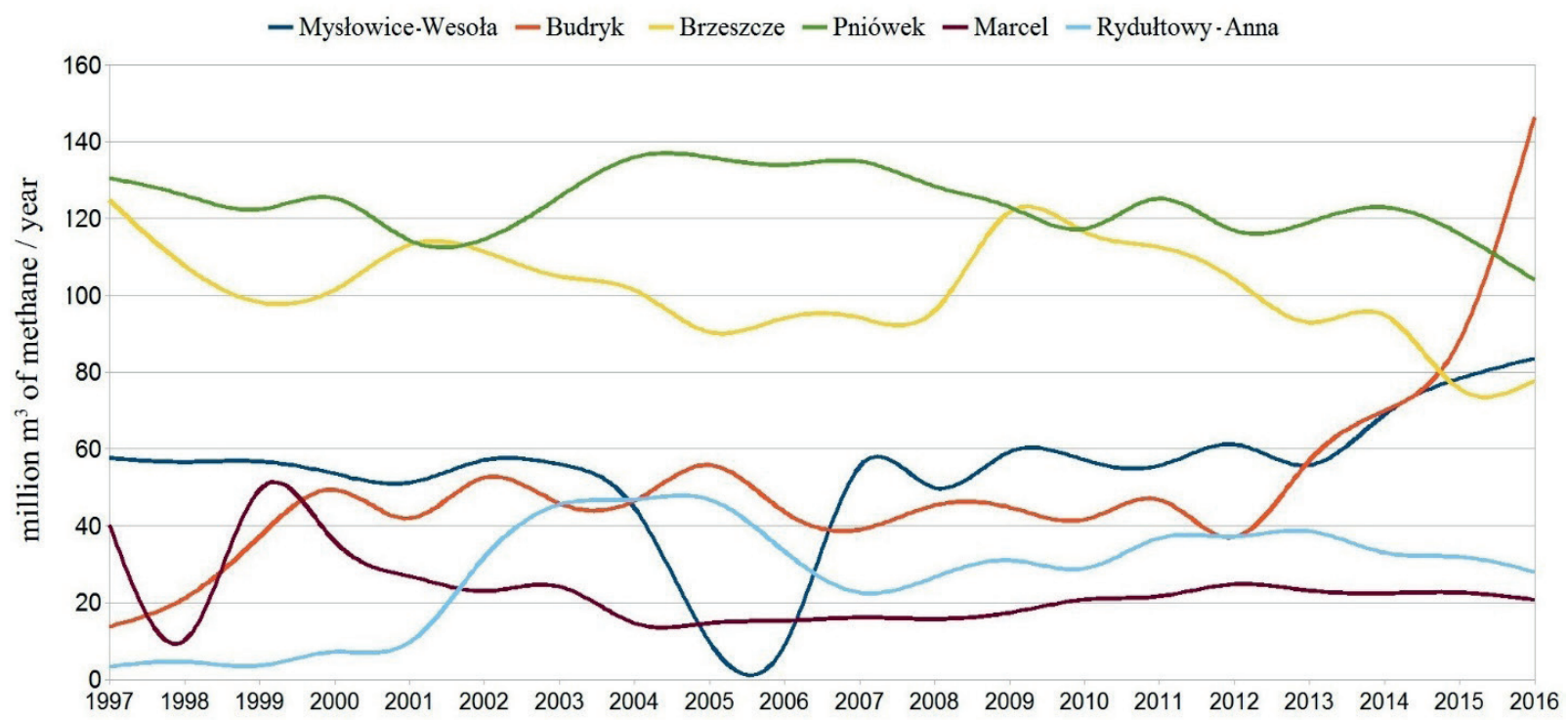

Fig. 5. Total methane emission in representative coal mines (Raport... 1998-2017) 
Since the beginning of the research to 2004 (eight years), on average 54.20 million $\mathrm{m}^{3}$ of $\mathrm{CH}_{4}$ (from 57.63 to 44.67 million $\mathrm{m}^{3}$ ) were emitted into the Mysłowice-Wesoła coal mine workings. Over the next two years (2005-2006) a huge drop was noticed. The sum of methane emissions in that two-year period was only 18.63 million $\mathrm{m}^{3}$ of $\mathrm{CH}_{4}$ (Raport... 1998-2017). In subsequent years, the total methane emissions returned to levels of over 50 million $\mathrm{m}^{3}$ of gas annually, with small fluctuations. In the last three-year study period (20142016), methane emissions increased rapidly, similarly to Budryk's emissions in the same time period. In 2014, over 68 million $\mathrm{m}^{3}$ of $\mathrm{CH}_{4}$ was emitted into coal mine workings. One year later, this figure was 78.34 million $\mathrm{m}^{3}$ and, in the last year, the highest methane emissions were noticed, of 83.56 million $\mathrm{m}^{3}$ of methane.

Rydułtowy-Anna in first four-year period emitted the least methane in comparison to other coal mines. Methane emissions from 3.35 to 7.17 million $\mathrm{m}^{3}$ were the lowest in the entire research period. Over the next two years (2001-2002) methane emissions increased rapidly to 31.77 million $\mathrm{m}^{3}$ of emitted gas (Raport... 1998-2017). In next three years, the course was flat, with an average 46.4 million $\mathrm{m}^{3}$ of methane emitted into coal mine workings. It was the period with the highest methane emission, since its subsequent years - from 2006 to the end of the study (2016) $-\mathrm{CH}_{4}$ emissions were significantly lower. The total methane emission trend was around 31.6 million $\mathrm{m}^{3}$ with small fluctuations.

Over 40 million $\mathrm{m}^{3}$ of $\mathrm{CH}_{4}$ was emitted in 1997 in the Marcel coal mine. The research on Marcel's emissions might have been seen to suggest high emission values in any future study period. But next year, four times less dangerous gas was emitted. In 1999, $\mathrm{CH}_{4}$ emission exceeded 49 million $\mathrm{m}^{3}$ of gas and it was the largest methane emission in Marcel's entire research period. In the next three years (2000-2002) total methane emissions decreased from 36.05 to 22.99 million $\mathrm{m}^{3}$ of $\mathrm{CH}_{4}$. In 2004 and 2005, over 14 million $\mathrm{m}^{3}$ of $\mathrm{CH}_{4}$ was emitted into coal mine workings. After that year, a gentle but constant increasing trend took place, but growing emission values stopped in 2012, when 24.79 million $\mathrm{m}^{3}$ of methane were emitted. The last four years (2013-2016) are characterized by decreasing methane emissions, closing the research period (2016) with 20.73 million $\mathrm{m}^{3}$ of emitted methane.

When we take a look at the total methane emissions for the whole of the USCB, we notice that $\mathrm{CH}_{4}$ emissions increase from 1998 to 2008. After eleven years of gentle and constant growth, (from 722.18 to 880.9 million $\mathrm{m}^{3}$ of $\mathrm{CH}_{4}$ ), figures fell for four years (Fig. 6). In 2009, over 855 million $\mathrm{m}^{3}$ of methane were emitted into Polish coal mine workings. Three years later, the total methane emissions were lower by 27.46 million $\mathrm{m}^{3}$ of $\mathrm{CH}_{4}$. The last four-year period of research had an increasing trend, from 847.79 to 933.76 million $\mathrm{m}^{3}$ of emitted gas.

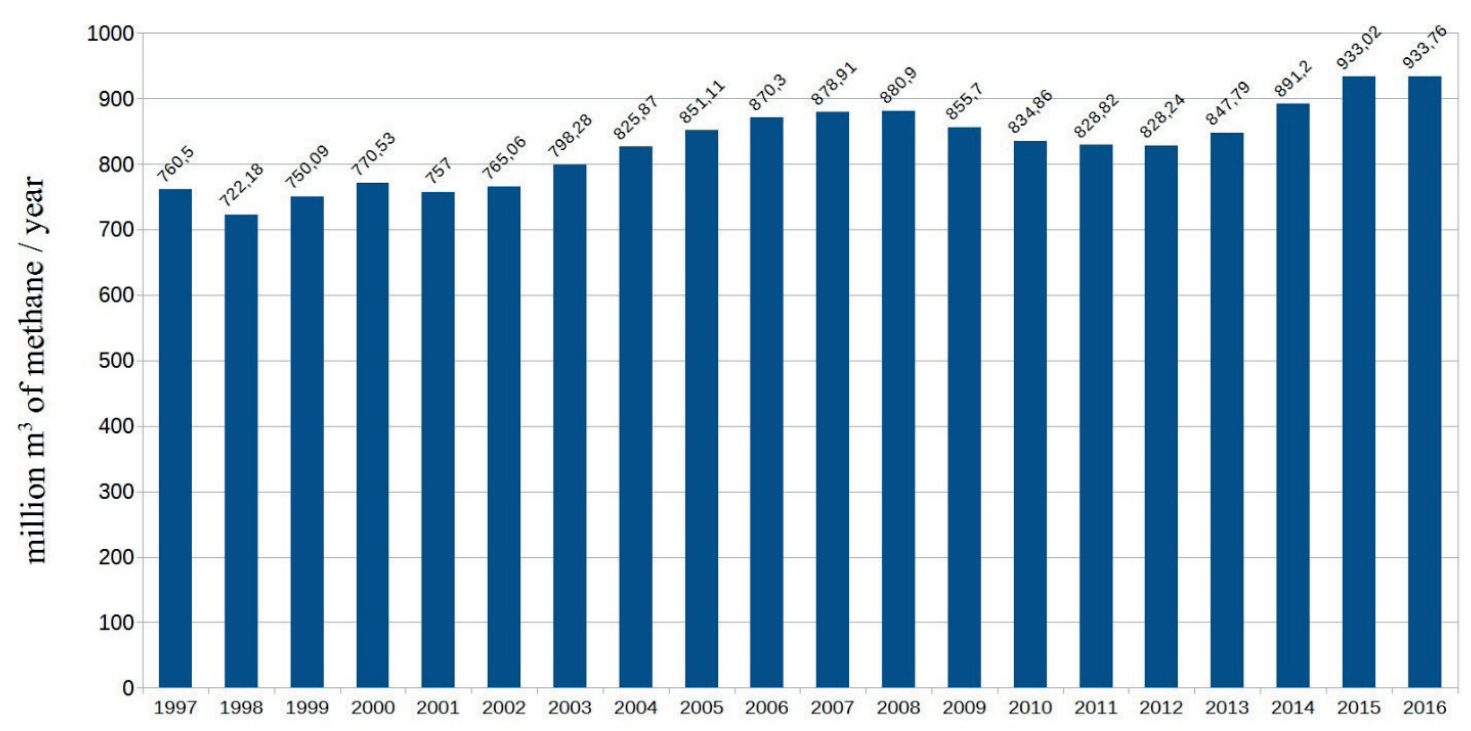

Fig. 6. Total methane emissions in the Upper Silesian Coal Basin (Raport... 1998-2017) 


\section{METHANE CAPTURED}

Total methane emission is a sum of the methane coming from mine degasification (methane drainage) and ventilation air methane - which is a mixture of mine gas and releasing methane to mine workings. Not all of the captured $\mathrm{CH}_{4}$ goes into the atmosphere by means of ventilation shafts. Some part of the gathered methane from mine degasification can be used for heating, cooling and power producing processes (Kozłowski \& Grębski 1982). It can be done only for inside mining processes, but it can be also be sold outside as power or heat (Szlązak 2015). Methane which is not used for energy purposes is released into the atmosphere. The efficiency of the gathered methane using was always above $50 \%$ which means more than half of captured methane was used to produce power, heat etc., but the rest of the undeveloped $\mathrm{CH}_{4}$ was released into the atmosphere (Tab. 2). Throughout the research period, the amount of methane used in the USCB hard coal mines was constantly rising with only partial decreases.

Table 2

Mine degasification, methane using and methane using efficiency in the USCB in 1997-2016 (Raport... 1998-2017)

\begin{tabular}{|c|c|c|c|}
\hline Year & $\begin{array}{l}\text { Methane captured } \\
{\left[\text { million } \mathrm{m}^{3}\right]}\end{array}$ & $\begin{array}{l}\text { Methane used } \\
{\left[\text { million } \mathbf{m}^{3}\right]}\end{array}$ & $\begin{array}{c}\text { Methane use efficiency } \\
{[\%]}\end{array}$ \\
\hline 1997 & 201.74 & 140.33 & 69.56 \\
\hline 1998 & 193.72 & 136.33 & 70.37 \\
\hline 1999 & 218.04 & 130.28 & 59.75 \\
\hline 2000 & 220.04 & 123.80 & 56.26 \\
\hline 2001 & 219.72 & 131.51 & 59.85 \\
\hline 2002 & 208.75 & 122.29 & 58.58 \\
\hline 2003 & 229.35 & 127.16 & 55.44 \\
\hline 2004 & 248.08 & 142.95 & 57.62 \\
\hline 2005 & 269.65 & 140.82 & 52.22 \\
\hline 2006 & 267.52 & 150.10 & 56.11 \\
\hline 2007 & 265.38 & 160.47 & 60.47 \\
\hline 2008 & 274.20 & 152.25 & 55.53 \\
\hline 2009 & 259.80 & 154.85 & 59.60 \\
\hline 2010 & 255.90 & 161.10 & 62.95 \\
\hline 2011 & 250.20 & 166.29 & 66.46 \\
\hline 2012 & 266.74 & 178.60 & 66.96 \\
\hline 2013 & 276.58 & 187.66 & 67.85 \\
\hline 2014 & 321.09 & 211.43 & 65.85 \\
\hline 2015 & 338.97 & 195.00 & 57.53 \\
\hline 2016 & 342.08 & 197.09 & 57.62 \\
\hline
\end{tabular}

\section{Specific methane emission}

The dependence of hard coal production and total methane emission causes the amount of specific methane emission, which describes how many $\mathrm{m}^{3}$ of methane were emitted with every single megagrams of hard coal extracted.

Within the entire research period (1997-2016), the Brzeszcze mine had the largest specific methane emissions among remaining studied coal mines in every year. From 1997 to 2002 the average methane emission per extracted megagram of hard coal was around $44.5 \mathrm{~m}^{3}$ (Raport... 19982017) with small fluctuations (Fig. 7). In 2003, a big increase took place, to $56.95 \mathrm{~m}^{3}$ of $\mathrm{CH}_{4} / \mathrm{Mg}$ but in the next two years the chart curve dropped to $42.11 \mathrm{~m}^{3}$ (2004) and $40.30 \mathrm{~m}^{3}$ (2005). In the next five-year period, specific methane emissions raised from $48.19 \mathrm{~m}^{3}$ (2006) to $87.62 \mathrm{~m}^{3}$ of released methane per megagram of coal extracted (2010). In 2010, the specific methane emission doubled in reference to the beginning of the study - 1997. 
The main reason for the doubling of the methane released into the coal mine workings with every single produced megagram of coal, was the hard coal output. When the difference in total methane emission was just 7\% (124.79 million $\mathrm{m}^{3}$ in 1997 and 116.53 million $\mathrm{m}^{3}$ of $\mathrm{CH}_{4}$ in 2010), the difference in hard coal production was much greater and significant. In 1997, 2.86 million $\mathrm{Mg}$ of coal was extracted in Brzeszcze but 11 years later it was just 1.33 million $\mathrm{Mg}, 53.5 \%$ lower than at the beginning of the study. When hard coal output was lower and total methane emission was the same or almost the same, specific methane emissions increased and brought more danger to the mine.

Between 2010 and 2013, when over $85 \mathrm{~m}^{3}$ of methane was released with every megagram of coal, a two-year fall period took place. In 2011 and 2012, the specific gassiness of coal mine was just below $59 \mathrm{~m}^{3}$. In the next three years, an increase period of specific methane emission was noticed $85.95 \mathrm{~m}^{3}$ in 2013, $100.51 \mathrm{~m}^{3}$ in 2014 and $99.79 \mathrm{~m}^{3}$ of methane per megagram in 2015. In 2014, the highest specific methane emission in all of the study period was noticed. In relation to 2010, hard coal production decreased by $29.3 \%$ ( $0.38 \mathrm{Mg}$ lower) and total methane emissions were $18.57 \%$ lower. From 2010 to the end of the study, total methane emissions decreased as much as hard coal output (Figs. 3 and 4) but hard coal production slowed more than methane emissions. As a result, in 2010 and 2014, the specific gassiness of the coal mines was dangerously high, exceeding $100 \mathrm{~m}^{3}$ in 2014 .

The second largest specific methane emission was studied in Pniówek mine situated in the IV gassy region. The chart course has a stable wave form with small fluctuations almost throughout the entire research period. We can divide the relative gassiness of the coal mine into two phases. First, from 1997 to 2007 when $\mathrm{CH}_{4}$ emission was below $40 \mathrm{~m}^{3}$ of gas per megagram of coal. The second phase lasted from 2008, when the volume of emitted $\mathrm{CH}_{4}$ per one megagram of coal exceeds $40 \mathrm{~m}^{3}$. In the first phase, the lowest specific methane emission was in $2002\left(30.51 \mathrm{~m}^{3} \mathrm{CH}_{4} / \mathrm{Mg}\right)$ but the highest in 1998 $\left(37.25 \mathrm{~m}^{3} \mathrm{CH}_{4} / \mathrm{Mg}\right)$. The average amount of emitted methane was $34.86 \mathrm{~m}^{3} \mathrm{CH}_{4} / \mathrm{Mg}$. In the second phase, $40 \mathrm{~m}^{3}$ of emitted methane per megagram was exceeded (41.90 $\mathrm{m}^{3} \mathrm{CH}_{4} / \mathrm{Mg}$ in 2008) and it lasted to 2014. The lowest emission in the second phase has been noticed in $2003\left(40.03 \mathrm{~m}^{3} \mathrm{CH}_{4} / \mathrm{Mg}\right)$ but was the highest in $2009\left(45.60 \mathrm{~m}^{3} \mathrm{CH}_{4} / \mathrm{Mg}\right)$ with an average $44.05 \mathrm{~m}^{3}$ of emitted $\mathrm{CH}_{4}$ per one produced megagram of coal. In last two years of studies (2015-2016) specific methane emissions were less than $40 \mathrm{~m}^{3} \mathrm{CH}_{4} / \mathrm{Mg}$.

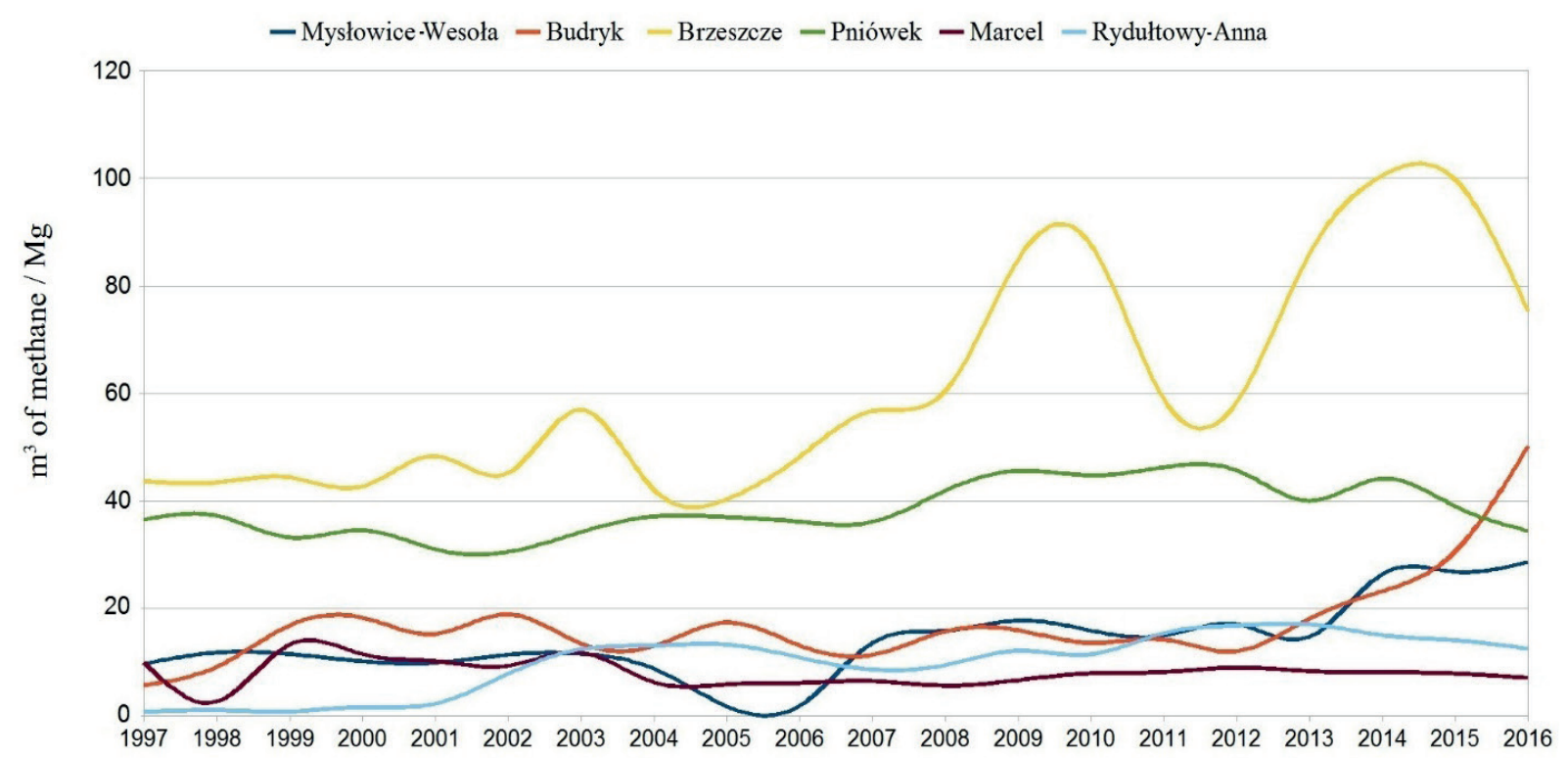

Fig. 7. Specific methane emissions in representative coal mines (Raport... 1998-2017) 
The relative gassiness of coal mines studied in other four mines (Mysłowice-Wesoła, Budryk, Marcel and Rudułtowy-Anna) was significantly lower than in Pniówek and Brzeszcze coal mines. From the beginning of the studies up to 2013, each of these mines emitted less than $20 \mathrm{~m}^{3} \mathrm{CH}_{4} / \mathrm{Mg}$ of coal. In 2014, both Mysłowice-Wesoła and Budryk increased their specific methane emission. The first of these two mines - Mysłowice-Wesoła emitted over $26 \mathrm{~m}^{3} \mathrm{CH}_{4} / \mathrm{Mg}$ in 2014 and 2015. In the last researched year (2016), $\mathrm{CH}_{4}$ emissions increased even more, up to $28.60 \mathrm{~m}^{3} \mathrm{CH}_{4} / \mathrm{Mg}$. This trend of rapid growing emission in the last three years of studies was caused by a decrease of hard coal production and a large increase in total methane emissions (Fig. 5). In 2014-2016, Mysłowice-Wesoła extracted less than 3 million Mg of coal yearly, which it was the smallest coal production period in the entire research term of this mine. On the other hand, the total methane emission had been increasing rapidly. In 2013, Mysłowice-Wesoła mine emitted 55.77 million $\mathrm{m}^{3}$ of $\mathrm{CH}_{4}$. This the specific gassiness of coal value was similar to emissions in 1997-1999, 2002 and 20102011, but in 2014 the methane emissions increased by $23.7 \%$, up to 68.99 million $\mathrm{m}^{3}$ of $\mathrm{CH}_{4}$. In the next two years, $\mathrm{CH}_{4}$ emission were even larger 78.34 million $\mathrm{m}^{3}$ in 2015 and 83.56 million $\mathrm{m}^{3}$ in 2016. The vast increase of total methane emission and coal production drop (to under 3 million $\mathrm{Mg}$ ) were the reasons for the rapidly growing specific methane emissions in last three years of studies.

Coal production in the Budryk mine in the last three years (2014-2016) was lower than in previous years but it was not the main reason for the rapidly growing specific gassiness of the coal mine. In 2014, the Budryk mine emitted 28\% more methane per one megagram of coal than in previous year $\left(18.12 \mathrm{~m}^{3} \mathrm{CH}_{4} / \mathrm{Mg}\right.$ in 2013 and $23.19 \mathrm{~m}^{3} \mathrm{CH}_{4} / \mathrm{Mg}$ in 2014). Over $30 \mathrm{~m}^{3} \mathrm{CH}_{4} / \mathrm{Mg}$ was emitted in 2015 and the highest emission was in the last year, 2016, when $50.24 \mathrm{~m}^{3} \mathrm{CH}_{4} / \mathrm{Mg}$ was emitted into the coal mine workings. The reason for the very fast specific methane emission increasing trend was coal production in coal seams lying 1,000 m under ground level. At this depth, exploitation reached the indigenous high methane zone where methane content increases very quickly. Coal seams operated at this depth (Upper
Silesian Sandstone Series) are characterized by methane content reaching about $10 \mathrm{~m}^{3} / \mathrm{Mg}$ coal $^{\text {daf }}$ (Grzybek \& Kędzior 2005).

\section{CONCLUSIONS}

In the analysed period covering 1997-2016, hard coal production in the entire USCB dropped by 55\% from 133 million $\mathrm{Mg}$ in 1997 to just 61 million $\mathrm{Mg}$ in 2016. In six representative coal mines, coal output also decreased. In the early years of research, the amount of coal production in the six mines was very diverse but after 2007 all mines were extracting between 2-3 million $\mathrm{Mg}$ of coal annually on a more stable level.

Total methane emissions in the entire USCB was increasing from 1998 to 2008. In subsequent years, lower emissions of $\mathrm{CH}_{4}$ was noticed, but in the last two years (2015-2016) the largest emission was recorded - over 900 million $\mathrm{m}^{3}$ of methane. From the six chosen mines, Brzeszcze and Pniówek recorded the highest emission of $\mathrm{CH}_{4}$. The thick Miocene cover and permeable fault action aided methane accumulation in these two coal mines. The rest of the selected mines emitted less than 60 million $\mathrm{m}^{3}$ of $\mathrm{CH}_{4}$ annually, but in the last four years of the study, total methane emissions in the Budryk mine suddenly increased, a trend connected with the indigenous high methane zone that occurs in the II gassy region between 800 and 1,200 m below ground. In the Mysłowice-Wesoła mine a rapid increase of $\mathrm{CH}_{4}$ emissions was noticed in the same time period.

The methane emission in Brzeszcze mine was the largest among the remaining studied coal mines in every year. The large decrease in coal output led to a huge increase in methane release with every extracted megagram of coal - over $100 \mathrm{~m}^{3} \mathrm{CH}_{4} / \mathrm{Mg}$. The rest of the mines noticed much lower specific $\mathrm{CH}_{4}$ emissions, and on a more stable level.

The location of the Upper Silesia Coal Basin has a significant influence on methane hazard. Thick and continuous Miocene cover prevented methane from escaping into the atmosphere in the geological past. Permeable fault action helps methane to migrate from deeper lying seams to shallower parts of deposits. The lack of Miocene cover naturally helped deposits to be degassed (northern and central regions). 


\section{REFERENCES}

Raport roczny o stanie podstawowych zagrożeń naturalnych $i$ technicznych $w$ górnictwie wegla kamiennego, 19982017. Wyd. GIG, Katowice.

Frączek R., 2005. Zwalczanie zagrożenia metanowego w kopalniach wegla kamiennego. Katedra Elektryfikacji i Automatyzacji Górnictwa Politechniki Śląskiej, Gliwice.

Grzybek I. \& Kędzior S., 2005. Zróżnicowanie warunków gazowych Górnośląskiego Zagłębia Węglowego a możliwości migracji metanu ze zlikwidowanych kopalń węgla kamiennego. Zeszyty Naukowe Politechniki Śląskiej. Górnictwo, 268, Wyd. Politechniki Śląskiej, Gliwice, $55-66$.

Honysz J., 2015. Górnictwo. 2. Wydawnictwo Naukowe "Śląsk", Katowice.

Kędzior S., 2009. Problem emisji i ujmowania metanu kopalnianego na przykładzie wybranych czynnych kopalń południowej części Górnośląskiego Zagłębia Węglowego. Górnictwo Odkrywkowe, 2-3, 79-83.

Kędzior S., 2012. Przystropowa strefa gazonośna w utworach karbonu południowej części Górnośląskiego Zagłębia Weglowego: występowanie, parametry zbiornikowe wegla oraz możliwości pozyskania metanu. Wydawnictwo Uniwersytetu Śląskiego, Katowice.

Kędzior S., 2015a. Methane contents and coal-rank variability in the Upper Silesian Coal Basin, Poland. International Journal of Coal Geology, 139, 152-164.

Kędzior S., 2015b. Emission and commercial utilization of coal mine methane in the Upper Silesian Coal Basin illustrated by the example of Katowice Coal Holding Company. Environmental \& Socio-economic Studies, $3,1,1-10$.

Kotarba M. \& Ney R., 1995 Węglowodory w utworach węglonośnych górnego karbonu Górnośląskiego Zagłębia Węglowego. [in]: Opracowanie modeli oraz bilansu generowania i akumulacji gazów w serii węglonośnej Górnośląskiego Zagłębia Weglowego, Wydawnictwo Centrum PPGSMiE, Kraków, 7-24.

Kotas A. (ed.) 1994. Coalbed Methane Potential of the Upper Silesian Coal Basin, Poland. Prace Państwowego Instytutu Geologicznego, 142, PIG, Warszawa.

Kozłowski B. \& Grębski Z., 1982. Odmetanowanie górotworu w kopalniach. Wyd. "Śląsk", Katowice.

Madeja J., 2017. JSW będzie wydobywać węgiel $z$ najgłębszego poziomu w Europie. [on-line] http://katowice.wyborcza.pl/ katowice/7,97222,21820414,jsw-bedzie-wydobywac-wegiel-z-najglebszego-poziomu-w.html [access: 29.12.2018].

Mizerski W., 2014. Geologia Polski. Wydawnictwo Naukowe PWN, Warszawa.

Szlązak N., 2015. Odmetanowanie górotworu w kopalniach węgla kamiennego. Wydawnictwa AGH, Kraków.

Tarnowski J., 1962. Statystyczna metoda wyznaczania wydzielania metanu. Prace Głównego Instytutu Górnictwa. Seria A. Komunikat, 287, Wydawnictwo Górniczo-Hutnicze, Kraków.

Tarnowski J., 1989. Geologiczne warunki występowania metanu w Górnoślaskiej Niecce Weglowej. Zeszyty Naukowe Politechniki Śląskiej. Górnictwo, 166, Dział Wydawnictw Politechniki Śląskiej, Gliwice. 